\title{
The Effect of Education, Experience and Occupation on Earnings: Evidence from Pakistan
}

\section{Hina Nazli}

\section{Introduction}

The theory of human capital posits a significant and positive relationship between earnings and work experience. This theory assumes a continuous increase in wages with employment experience at different levels of schooling. Several studies have established that earnings rise rapidly as the level of educational attainment improves. Similarly increase in work experience adds to skills, makes an individual more productive and hence leads to higher earnings. Education provides not only an initial labour market advantage, but also cumulative benefits over the working life. Therefore, it is misleading to assume a uniform rate of return to experience at different levels of education.

In order to examine the impact of education and experience on earnings, Mincer (1974) in his seminal article introduced an interaction term of education and experience as an explanatory variable in the earning function to account for the cumulative effect of both these variables. He found a negative and significant coefficient in estimates based on US data and concluded that more educated workers attain peak earnings with less experience. However, the opposite impact is generally estimated and is extensively documented in the literature ${ }^{1}$. There are however, some exceptions; for example, using data for Morocco, Psacharopoulos (1981) did not observe any significant impact of this interaction on earnings. For British data, Psacharopoulos and Layard (1979) found that the value of the interactions terms increases with either increase in education or experience for different levels of both these variables. More recently, Connolly and Gottschalk (2003) have found that the returns to tenure increase with education, but that returns to experience decrease with educational attainment in the US. This indicates that the less educated have higher returns to education. In examining the role of ICT technology in the

\footnotetext{
${ }^{*}$ Senior Research Analyst at the Innovative Development Strategies (Pvt) Ltd Islamabad Pakistan.

${ }^{1}$ See Blaug (1976) for Thailand, Anderson (1980) for El Salvador, Knight and Sabot (1981) for Tanzania, Layard and Psacharopoulos (1974) for United States, Mazumdar (1981) for Malaysia, Byron and Takahashi (1989) for Indonesia, Byron and Manaloto (1990) for China, Knight and Sabot (1990) for Kenya and Tanzania; and Brunello and Comi (2000) for eleven European countries.
} 
UK, Kirby and Riley (2004) found that the return to an extra year of schooling is greater relative to an extra year of job-specific experience. The overall conclusion of the international studies examining the returns to education ${ }^{2}$ is that higher levels of education lead to higher earnings as the employment experience lengthens.

While studies examining the effect of education on earnings are manifold for Pakistan, no study has used the education-experience interaction variable. This study seeks to fill the gap.

Acquired skills through education and training play an important role in the choice of occupation that in turn affects individual earning as different occupations require different characteristics of workers. In order to get a suitable reward, educated individuals look for such jobs that match with their education. On the other hand, the uneducated want to enter jobs that match with their skills and where rewards are higher. By using an "occupation production function", Knight (1979) demonstrated that certain levels of education are 'necessary', 'appropriate' or 'excessive' for a particular job. In other words, a worker with a certain level of education may be more productive in one occupation than the other and would thus receive higher wages. For Tanzania and Kenya, Beyer and Knight (1989) and Knight and Sabot (1990) found a positive relationship between human capital variables and the level of skills an individual has. They concluded that by introducing occupation in the earning function, one can better understand the mechanism by which the returns to education fall; and, more generally the way in which the labour market operates. Using data on U.S. engineers and the position of engineering jobs within firms, Ferrall (1997) observed that most of the returns to experience and to assignment to higher hierarchy levels within firms are caused by skill accumulation and self-selection rather than technological differences across hierarchy levels.

The role of occupation in determining earnings has been highlighted by several studies ${ }^{3}$. For Pakistan various studies have observed that workers belonging to different occupations receive significantly different returns ${ }^{4}$. Khan and Irfan (1985) found differences in earnings based on interregional as well as occupational differences. The expected average earnings for urban areas were found to be 18 percent higher than those for rural areas whereas clerical, sales and service workers were expected to earn 6 percent lower than the blue-collar

\footnotetext{
${ }^{2}$ for details see Nasir and Nazli (2000)

${ }^{3}$ For example see Knight (1989) for a detailed review.

${ }^{4}$ See, Haque (1977); Khan and Irfan (1985); Ahmad, et al (1991);Ashraf and Ashraf (1993); Shabbir (1994); Nasir (1998); Fafchamps and Quisumbing (1998); Nasir and Nazli (2000); and Malik and Nazli (2003).
} 
and agricultural workers. Another important factor that the authors captured in explaining the earning function of the earner was the effect of the income of the first earner (usually father) on the second earner (off spring). Their results indicated that the income of the second earner was positively related with that of the first earner and that the effect was strongest for the administrative and professional group of workers. Hence the income of the first earner affected that of the second earner through occupational status. Fafchamps and Quisumbing (1998) using data from the International Food Policy Research Institute report that increase in earnings associated with an increase in human capital are partly due to the increase in productivity and partly to the reallocation of labour from farm to non-farm activity. Hence increase in education induces households to shift labour away from low productivity farm activities to high productivity non-farm activities; which results in a greater increase in earnings. Malik and Nazli (2003) found a significant poverty reduction effect of skilled occupations both in urban as well as rural areas.

This paper attempts to explain the effect of education, experience and occupation on individual earnings in Pakistan. The exploration of this interlinked connection is of considerable importance at the academic as well as policy levels. From the academic point of view, it highlights the importance of the collection of data on years of schooling and past and present employment history of work experience. These data are sadly lacking in most of the household surveys. At the policy level, it highlights the importance of education and training expansion, and brings to light the very important issue of uneven employment opportunities in different regions of Pakistan.

The education system in Pakistan is still under-developed. Extremely low levels of adult literacy, low enrolment and high drop out rates at the primary level, high student-teacher ratios, wide gender and regional disparities, and low levels of public investment are both symptoms and indicators of the very dismal performance of the education sector ${ }^{5}$. The literacy rate for the population 10 years and above was 45 per cent in 2001-02; 58 percent for males and 32 percent for females. Despite many efforts and various government programmes, no change in the literacy rate has been found between 1998-99 and 2001-02 [for details see PIHS (2001-02)] ${ }^{6}$. This not only indicates that a large proportion of the population is still illiterate but also highlights the significant differences between genders. This situation is far worse if regional disparities are taken into account as gender differential is more pronounced in

\footnotetext{
${ }^{5}$ Data in this section except where otherwise indicated are from the Pakistan Economic Survey (2002-03).

${ }^{6}$ Official estimates however claim that the literacy rate has increased to 51.6 percent in 2003 [Pakistan Economic Survey (2002-03)].
} 
rural areas [see Arif, Nazli, and Haq (2000)]. The gross enrolment rate showed a remarkable improvement during 1951-1991. This rate increased to 98 percent by 1998-99. It has sadly declined to 91 percent in 2001-02. Rising trends in poverty during the 1990s may be the one major cause for this decline since for several parents, especially in rural areas, it has now become more difficult to send children to school. In addition, high drop out rates also indicate the poor quality of education. PIHS (2001-02) indicates that 13 percent of children of ages 15-19 years who have enrolled in primary school, drop out before completing primary (class 5). However, the largest drop out rate is at the end of the primary level, with 28 percent dropping out before reaching the end of class six.

Due to the poor performance of the education sector, Pakistan's labour market has remained dominated by less educated and unskilled manpower. In this situation, it becomes important to examine the role of education, experience and occupation on earnings. Because of the non-availability of data on the years of work experience, there is no literature available in Pakistan that examines the returns to experience. The recently conducted nation-wide survey, Pakistan Socio Economic Survey (PSES) has information on various economic and socio-economic variables including the years of employment experience. This information permits an examination of the effect of education, experience and choice of occupation on individual earnings.

The rest of the paper is organised as follows: section 2 presents an outline of the methodology used in the empirical estimation and section 3 describes the data and variables in the model. Results are presented in section 4. Conclusions and policy implications are presented in the last section.

\section{Methodology}

The simple human capital model developed originally by Becker (1964) and used by Mincer (1974) can be written as:

$$
\ln Y=f\left(S, E, E^{2}\right)
$$

Where $\ln Y$ stands for natural logarithm of monthly earnings, $S$ represents completed years of schooling, and $\mathrm{E}$ is the labour market experience of the ith individual. The experience-earning profile indicates that earnings rise rapidly in the first years of work life, reaches a peak, and then tends to fall after the mid-career; implying that the increase in earnings in the early years of work life is due to the increase in productivity that is gained through the level of education, technical training and experience of work. The age at which earnings are maximum depends on the level of schooling. If we say that 
education plays an important role in enhancing productivity and efficiency of individuals then the more educated should have a steeper age-earning profile than the uneducated. Therefore, as already mentioned, in order to examine the joint effect of education and experience, it is important to incorporate the effect of education in the age-earning profile by specifying the interaction term between schooling and experience. In order to test the interaction effect we will estimate the following equations:

$$
\begin{aligned}
& \ln Y=f\left(S, E, E^{2}, \sum Z_{k}\right) \\
& \ln Y=f\left(S, E, E^{2}, S . E, \sum Z_{k}\right) \\
& \ln Y=f\left(\sum S_{i}, \sum E_{j}, \sum Z_{k}\right) \\
& \ln Y=f\left(\sum S_{i}, \sum E_{j}, \sum S_{i} E_{j}, \sum Z_{k}\right)
\end{aligned}
$$

Where $S_{i}$ and $E_{j}$ are is the sets of four dummy variables indicating different levels of education and experience respectively. These levels are:

$S_{1}=$ No education

$S_{2}=$ Primary education $(1-5$ years $)$.

$S_{3}=$ Middle education (6-8 years).

$S_{4}=$ Matric and above.

$E_{1}=$ Employment experience $1-4$ years

$E_{2}=$ Employment Experience 4-8 years.

$E_{3}=$ Employment experience 8-12 years.

$E_{4}=$ Employment experience 12 years or more.

$Z_{k}=$ Vector of other explanatory variables. In our model, this vector includes dummies for technical training, sex, and provinces.

Equation 3 examines the joint effect of education and experience. A positive coefficient of interaction term implies that the joint effect of these two variables is stronger than their individual effects at given values. Equation 4 explains what the returns to education are and experience at different levels of 
these two variables. Equation 5 introduces the interaction terms of different levels of education and experience and examines the effect of different levels of experience (education), keeping education (experience) constant. Another way of looking at the joint effect of education and experience on earning is to examine the coefficient of education in the earning equation that is stratified by the length of experience or to examine the coefficients of experience and its squared term in the earning equation that is stratified by the levels of education.

\section{Data}

In order to examine the impact of structural adjustment policies on income distribution, poverty alleviation, and social welfare, the Pakistan Institute of Development Economics (PIDE), launched a project entitled "Micro Impact of Macroeconomic and Adjustment Policies" funded by the International Development Research Center (IDRC), Canada. To achieve the goals of this project, a household survey in the rural and urban areas of all provinces of Pakistan was conducted during 1998-997. This survey was called the "Pakistan Socio-Economic Survey (PSES) 1998-99" [for details see Arif, et al (1999)]. For this survey, a two stage stratified random sampling design was adopted so as to select a sample of 3564 households. FATA, FANA, and Military restricted areas were excluded from the universe. The urban/rural distribution of the sample was 1296 and 2268 households respectively.

In addition to education, experience and occupation, the effect of technical training on earning is also examined in this study. This effect has been found positive and substantial in many developing countries ${ }^{8}$. The PSES has information on the years of technical training that permits this estimation. We use a dummy variable that takes the value ' 1 ' if an individual received technical training and ' 0 ' otherwise. In addition, the regional, provincial and gender imbalances in the provision of the limited available social services are quite pronounced in Pakistan'. These effects are controlled for by introducing dummy variables for region, provinces and gender.

For the purpose of analysis we have restricted our sample to wage earners and salaried persons. Our sample has 1271 individuals; 1151 males and 120 females. Table 1 presents descriptive statistics on key variables. According

\footnotetext{
${ }^{7}$ In order to make this data set a panel, a second round of survey on the same household has recently been completed. However, the results of the present study are based on the data collected in 1998-99.

8 Jimenez and Kugler (1987); van der Gaag and Vijverberg (1989); Khandker (1990); Nasir (1999); and Nasir and Nazli (2000).

${ }^{9}$ Nasir and Nazli (2000) cited various studies that examined these differentials in detail.
} 
to the statistics in Table 1, the average age of the individuals included in the sample is 35 years. The mean years of schooling are 7.67 years and 25 percent individuals have no formal education. Almost 25 percent individuals have education below matric ${ }^{10}$ and 50 percent are above matric. Mean experience is observed 11 years. Nearly 59 percent wage earners and salaried persons live in urban areas. On average an individual earns Rs. 3495 per month. In our sample, there are only 11 percent individuals who received technical training. A majority of wage earners belong to the Punjab, followed by Sindh and NWFP.

Table1: Mean, Standard Deviation and Brief Definitions of Important Variables

\begin{tabular}{|c|c|c|c|}
\hline Variables & Mean & SD & Variables Definitions \\
\hline $\mathrm{Y}$ & 3494.65 & 2591.08 & $\begin{array}{l}\text { Individual's monthly earnings in rupees consist of } \\
\text { wages and salaries. }\end{array}$ \\
\hline Age & 34.89 & 12.01 & Age of an individual in years. \\
\hline $\mathrm{S}$ & 7.67 & 5.42 & Completed years of schooling. \\
\hline $\mathrm{E}$ & 11.08 & 8.72 & Total Years of labour market experience. \\
\hline MALE & 0.90 & 0.29 & $\begin{array}{l}\text { Dichotomous variable equal to } 1 \text { if individual is } \\
\text { male. }\end{array}$ \\
\hline Urban & 0.59 & 0.49 & $\begin{array}{l}\text { Dichotomous variable equal to } 1 \text { if individual } \\
\text { belongs to urban area. }\end{array}$ \\
\hline Training & 0.11 & 0.32 & $\begin{array}{l}\text { Dichotomous variable equal to } 1 \text { if individual } \\
\text { received any technical training. }\end{array}$ \\
\hline Prof & 0.13 & 0.33 & $\begin{array}{l}\text { Dichotomous variable equal to } 1 \text { if individual } \\
\text { belongs to "Professional" category of occupation. }\end{array}$ \\
\hline Tech & 0.25 & 0.43 & $\begin{array}{l}\text { Dichotomous variable equal to } 1 \text { if individual } \\
\text { belongs to "Technician/Clerk" worker category of } \\
\text { occupation. }\end{array}$ \\
\hline Service & 0.56 & 0.49 & $\begin{array}{l}\text { Dichotomous variable equal to } 1 \text { if individual } \\
\text { belongs to "Service" category of occupation. }\end{array}$ \\
\hline Labour & 0.05 & 0.22 & $\begin{array}{l}\text { Dichotomous variable equal to } 1 \text { if individual } \\
\text { belongs to "Labour" category of occupation. }\end{array}$ \\
\hline Punjab & 0.46 & 0.49 & $\begin{array}{l}\text { Dichotomous variable equal to } 1 \text { if individual } \\
\text { belongs to Punjab }\end{array}$ \\
\hline Sindh & 0.33 & 0.47 & $\begin{array}{l}\text { Dichotomous variable equal to } 1 \text { if individual } \\
\text { belongs to Sindh }\end{array}$ \\
\hline NWFP & 0.14 & 0.34 & $\begin{array}{l}\text { Dichotomous variable equal to } 1 \text { if individual } \\
\text { belongs to NWFP }\end{array}$ \\
\hline Balochistan & 0.06 & 0.24 & $\begin{array}{l}\text { Dichotomous variable equal to } 1 \text { if individual } \\
\text { belongs to Balochistan }\end{array}$ \\
\hline
\end{tabular}

\footnotetext{
${ }^{10}$ Exam taken after ten years of education
} 


\section{Results}

In the sample of 1271 individuals, 25 percent were uneducated and 51 percent had more than eight years of education. Among the uneducated, 34 percent belonged to the highest and 21 percent to the lowest experience groups. On the other hand, the concentration of those who belonged to the highest education group was in the lowest experience group (53\%). This implies the presence of the trade off between education and years of experience.

Before analysing the results, it is useful to look at the average earnings across each educational and experience category for different age groups. Table 2 presents the mean earnings at different levels of education and experience by 10 age groups. The data in this Table confirm a concave age-earning relationship. There is, among the educated, lower earning differentials across educational levels at younger ages (less than 30 years). This differential reaches a maximum in the group 40-45 years ${ }^{11}$. Looking at educational levels, highest earnings are found associated with highest level of education [see Chart 1]. This chart shows a flatter age-earning profile for the group $S_{1}$ as compared to all other groups. This means that the earnings of the uneducated remain substantially lower than those who have some education.

Table 2: Mean Income at Different Levels of Education and Experience by Age Groups

\begin{tabular}{|c|c|c|c|c|c|c|c|c|c|}
\hline \multirow{3}{*}{$\begin{array}{c}\text { Age } \\
\text { groups }\end{array}$} & \multicolumn{9}{|c|}{ (Rupees) } \\
\hline & \multicolumn{4}{|c|}{ Educational groups } & \multicolumn{4}{|c|}{ Experience groups } & \multirow[t]{2}{*}{ Total } \\
\hline & S1 & S2 & S3 & S4 & E1 & E2 & E3 & E4 & \\
\hline $15-19$ & 1,482 & 1,404 & 2,122 & 1,838 & 1,685 & 2,417 & - & - & 1,737 \\
\hline $20-24$ & 1,881 & 1,837 & 2,262 & 2,690 & 2,412 & 1,962 & 1,675 & 1,350 & 2,318 \\
\hline $25-29$ & 2,370 & 2,603 & 2,683 & 3,536 & 3,468 & 2,764 & 3,578 & 2,100 & 3,168 \\
\hline $30-34$ & 2,621 & 2,539 & 2,920 & 4,507 & 3,752 & 3,774 & 4,029 & 3,293 & 3,822 \\
\hline $35-39$ & 2,883 & 3,217 & 3,359 & 4,740 & 3,263 & 4,240 & 3,752 & 4,052 & 3,925 \\
\hline $40-44$ & 2,899 & 4,240 & 3,391 & 5,913 & 5,521 & 4,358 & 5,302 & 4,550 & 4,729 \\
\hline $45-49$ & 3,218 & 3,496 & 4,525 & 6,432 & 2,801 & 4,840 & 4,276 & 5,496 & 4,908 \\
\hline $50-54$ & 2,466 & 2,710 & 3,498 & 6,162 & 3,588 & 2,075 & 2,680 & 4,288 & 4,002 \\
\hline $55-59$ & 2,574 & 2,401 & 3,159 & 4,925 & 3,500 & 2,798 & 2,240 & 3,580 & 3,403 \\
\hline $60+$ & 1,690 & 2,375 & 4,050 & 4,083 & 1,961 & 1,167 & 2,146 & 2,987 & 2,642 \\
\hline Total & 2,430 & 2,650 & 2,906 & 4,372 & 2,783 & 3,381 & 4,003 & 4,300 & 3,495 \\
\hline
\end{tabular}

${ }^{11}$ For the US, Ehrenberg and Smith (1997) found a smaller wage differential among young workers (below 27) with and without a university degree. This difference reaches its maximum between the ages 40 and 50 years. Earnings reached a maximum in the age group 45-49 years and show a declining trend afterwards. 
Table 2 shows a positive relationship between experience and earnings. An interesting finding is that at early ages, smaller earnings are associated with higher experience. After the age of 35 years, this situation becomes reverse. For example in the age group 20-24, individuals belonging to lowest experience category, earn 78 percent more than those in highest experience category. This may be due to the fact that the individuals with less experience have higher levels of education that leads to higher earnings.

\section{Chart 1: Age-Earnings Profile at Different Levels of} Education

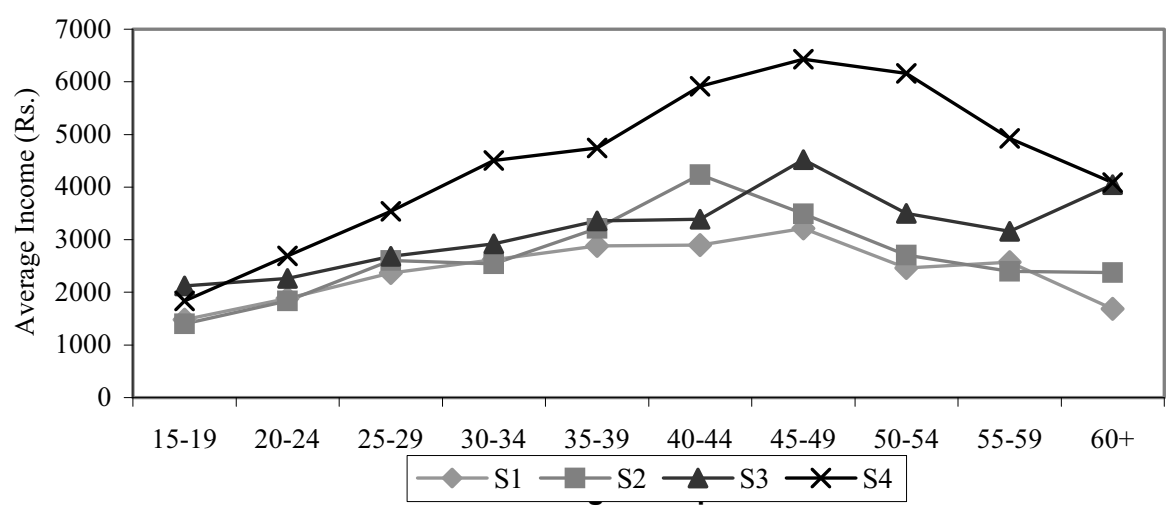

\section{Gender Differentials in Age-Earning Profile}

The existence of a wide gender gap in human capital accumulation is evidenced by various studies in Pakistan ${ }^{12}$. The PSES (1998-99) reports vast gender disparities in literacy and enrolment rates. The literacy rate among females is half that of males' literacy rate for the whole of Pakistan. This difference is much higher in rural areas. In our sample there are only 120 females; among them 28 fall in the first education group $S_{1}$, that is 'no education'; only 6 in the second group $S_{2}$; no one in the third group $S_{3}$; and 86 belong to the fourth education group $S_{4}$. This means that participation of women in the wage market is higher for those who are either uneducated or have education more than 8 years. In this sample 69 percent women are found in urban areas. Table 3 presents the age-earning profiles across gender. This Table shows wide gender disparity in the mean earnings. It is interesting

12 Sabot (1992); and Alderman, Behrman, Ross and Sabot (1996b); Sawada (1997); Shabbir (1993); Ashraf and Ashraf (1993a, 1993b, and 1996); and Nasir (1999). 
to note that mean earnings of females for the age group 30-39 are higher than that of males. After this age group, the gap becomes wider in favour of males. Looking across the educational groups, one can note that this differential is more pronounced for the uneducated group [see Appendix Chart 1]. In this group female earnings exhibit a fluctuating pattern. Maximum earnings are found for the age group 35-39, whereas males attain peak earnings in the age group 45-49. Surprisingly, in this age group, female earnings were found lowest. In the education group $S_{2}$ no women of the ages between 25-44 years were found working for wages. This reflects the general pattern of a typical Pakistani woman, who due to her household and child responsibilities in the early years of married life cannot participate in productive economic activities $^{13}$. The highest educational group portrays a very interesting picture for the age group 35-49 years, female earnings are found higher than that of males $^{14}$. The age-earning profile of this educational group is presented in the Appendix Chart 2. This chart shows a considerable difference in the earnings of males and females for the age group 45-49 years in favour of females. In this educational group, both males and females attain peak earnings in the age group 45-49 years.

Table 3: Age-Earning Profile by Gender

\begin{tabular}{|c|c|c|c|c|c|c|c|c|c|c|}
\hline \multirow{3}{*}{$\begin{array}{l} \\
\text { Age } \\
\text { groups }\end{array}$} & \multirow{2}{*}{\multicolumn{2}{|c|}{ S1 }} & \multirow[b]{2}{*}{ S2 } & \multicolumn{7}{|c|}{ (Rupees) } \\
\hline & & & & & S3 & & S4 & & Total & \\
\hline & $\overline{\text { Male }}$ & Female & Male & Female & Male & Female & Male & Female & Male & Female \\
\hline $15-19$ & 1,472 & 300 & 1,373 & 1,800 & 2,122 & - & 1,863 & 1,680 & 1,756 & 1,428 \\
\hline $20-24$ & 1,843 & 500 & 1,837 & 1,800 & 2,262 & - & 2,859 & 1,922 & 2,370 & 2,370 \\
\hline $25-29$ & 2,568 & 1,105 & 2,603 & - & 2,683 & - & 3,642 & 3,021 & 3,242 & 2,679 \\
\hline $30-34$ & 2,680 & 500 & 2,539 & - & 2,920 & - & 4,577 & 4,123 & 3,809 & 3,932 \\
\hline $35-39$ & 2,951 & 1,750 & 3,217 & - & 3,359 & - & 4,677 & 5,144 & 3,866 & 4,578 \\
\hline $40-44$ & 3,050 & 1,233 & 4,240 & - & 3,391 & - & 5,900 & 6,050 & 4,749 & 4,444 \\
\hline $45-49$ & 3,466 & 350 & 3,614 & 2,200 & 4,525 & - & 6,401 & 8,000 & 5,018 & 2,620 \\
\hline $50-54$ & 2,768 & 957 & 2,883 & 1,500 & 3,498 & - & 6,374 & 4,800 & 4,239 & 2,476 \\
\hline $55-59$ & 2,814 & 733 & 2,444 & 2,100 & 3,159 & - & 5,086 & 3,400 & 3,560 & 1,850 \\
\hline $60+$ & 1,831 & 884 & 2,375 & - & 4,050 & - & 4,083 & - & 2,792 & 884 \\
\hline Total & 2,576 & 939 & 2,678 & 1,933 & 2,907 & - & 4,491 & 3,603 & 3,557 & 2,898 \\
\hline
\end{tabular}

${ }^{13}$ In our sample, 55 percent women are currently married. Among them 65 percent belong to the age group 25-44 years.

${ }^{14}$ In this age group a larger proportion of females $(35 \%)$ have education equal to or more than 14 years. 


\section{Regional Differentials in Age-Earning Profile}

The regional imbalances in the provision of limited available social services are more pronounced in Pakistan. Rural areas are not only underdeveloped in terms of physical infrastructure but also neglected in gaining basic amenities. According to the PIHS (2001-02), the literacy rate in urban areas is 64 percent and in rural areas it is 36 percent. The gross enrolment rate was 94 percent in urban areas and 68 percent in rural areas. Because of these differences low returns to education are observed in rural areas [Shabbir (1993 and 1994); Nasir (1999); and Nasir and Nazli (2000)]. In our sample of 1271 individuals, 756 belong to urban areas and 515 are from rural areas. In this sample the urban literacy rate is found to be 63 percent and in rural areas it is 47 percent. Similar differences can be seen in the occupational distribution. For example, 70 percent of the professionals are from urban areas.

\section{Results of Estimated Equations:}

The results based on the estimated equations (2, 3, 4, and 5) are presented below. The estimates are reported in Table 4. According to equation 2 , the rates of returns to education are 5 percent and returns to experience are 7 percent. An individual attains peak earnings with an experience of 21 years. Evaluating at mean experience, we find that an individual with 11.08 years experience earns 54 percent higher than the non-experienced individual. There are also significant gender, regional and provincial differences. The coefficients of occupation dummies indicate that choice of occupation is an important determinant of individual earnings. Higher earnings are associated with better paying occupations (Professionals). This equation shows that returns to technical training are nearly 9 percent. 
Table 4: Estimated Equations with and without Education-Experience Interaction Terms

\begin{tabular}{|c|c|c|c|c|c|c|c|c|}
\hline & \multicolumn{2}{|c|}{ Equation 2} & \multicolumn{2}{|c|}{ Equation 3} & \multicolumn{2}{|c|}{ Equation 4} & \multicolumn{2}{|c|}{ Equation 5} \\
\hline & $\beta$ & t-value & $\beta$ & t-value & $\beta$ & t-value & $\beta$ & t-value \\
\hline Const & 6.26 & (65.68) & 6.35 & (61.10) & 6.46 & $(66.12)$ & 6.55 & $(59.90)$ \\
\hline $\mathrm{S}$ & $0.048^{*}$ & $(14.45)$ & $0.040 *$ & $(8.19)$ & & & & \\
\hline E & $0.067^{*}$ & (12.41) & $0.060^{*}$ & $(9.71)$ & & & & \\
\hline $\mathrm{E}^{2}$ & 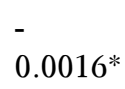 & $(-9.69)$ & $-0.0015^{*}$ & $(-9.19)$ & & & & \\
\hline S.E & & & $0.0007^{* *}$ & $(2.19)$ & & & & \\
\hline $\mathrm{S}_{2}$ & & & & & $0.175^{*}$ & $(3.22)$ & 0.098 & $(1.08)$ \\
\hline $\mathrm{S}_{3}$ & & & & & $0.247^{*}$ & (4.45) & 0.147 & $(0.15)$ \\
\hline $\mathrm{S}_{4}$ & & & & & $0.494^{*}$ & (11.52) & $0.419^{*}$ & $(6.07)$ \\
\hline $\mathrm{E}_{2}$ & & & & & $0.229^{*}$ & (5.71) & $0.216^{*}$ & $(2.56)$ \\
\hline $\mathrm{E}_{3}$ & & & & & $0.342^{*}$ & (6.89) & $0.275^{*}$ & $(2.74)$ \\
\hline $\mathrm{E}_{4}$ & & & & & $0.434^{*}$ & (10.64) & $0.278^{*}$ & $(3.60)$ \\
\hline $\mathrm{S}_{2} \cdot \mathrm{E}_{2}$ & & & & & & & 0.090 & $(0.65)$ \\
\hline $\mathrm{S}_{2} \cdot \mathrm{E}_{3}$ & & & & & & & 0.032 & $(0.17)$ \\
\hline $\mathrm{S}_{2} \cdot \mathrm{E}_{4}$ & & & & & & & 0.135 & $(0.09)$ \\
\hline $\mathrm{S}_{3} \cdot \mathrm{E}_{2}$ & & & & & & & 0.056 & $(0.39)$ \\
\hline $\mathrm{S}_{3} \cdot \mathrm{E}_{3}$ & & & & & & & 0.180 & $(1.05)$ \\
\hline $\mathrm{S}_{3} \cdot \mathrm{E}_{4}$ & & & & & & & 0.230 & $(1.55)$ \\
\hline $\mathrm{S}_{4} \cdot \mathrm{E}_{2}$ & & & & & & & 0.016 & $(0.15)$ \\
\hline $\mathrm{S}_{4} \cdot \mathrm{E}_{3}$ & & & & & & & 0.072 & $(0.59)$ \\
\hline $\mathrm{S}_{4} \cdot \mathrm{E}_{4}$ & & & & & & & $0.241^{* *}$ & $(2.50)$ \\
\hline Train & $0.094^{*}$ & (1.99) & $0.090^{*}$ & $(1.92)$ & $0.119^{*}$ & (2.43) & $0.112^{* *}$ & $(2.28)$ \\
\hline Prof & $0.502^{*}$ & $(6.10)$ & $0.489^{*}$ & $(8.28)$ & $0.591^{*}$ & (6.96) & $0.577^{*}$ & $(6.76)$ \\
\hline Tech & $0.315^{*}$ & (4.17) & $0.308^{*}$ & $(5.94)$ & $0.367^{*}$ & (4.66) & $0.356^{*}$ & (4.49) \\
\hline Service & $0.258^{*}$ & (3.82) & $0.250^{*}$ & $(4.08)$ & $0.246^{*}$ & (3.49) & $0.239^{*}$ & $(3.37)$ \\
\hline Male & $0.449^{*}$ & (8.54) & $0.437^{*}$ & $(8.28)$ & $0.471^{*}$ & (8.54) & $0.434^{*}$ & $(8.17)$ \\
\hline Urban & $0.150^{*}$ & $(4.81)$ & $0.118^{*}$ & $(3.73)$ & $0.153^{*}$ & (4.61) & $0.150^{*}$ & $(4.50)$ \\
\hline Punjab & 0.041 & $(0.91)$ & 0.034 & $(0.77)$ & 0.053 & (1.13) & 0.047 & $(1.01)$ \\
\hline Sind & $0.189^{*}$ & (3.97) & $0.190^{*}$ & $(4.01)$ & $0.236^{*}$ & (4.76) & $0.239^{*}$ & $(4.82)$ \\
\hline Baloch & $0.380^{*}$ & (5.37) & $0.357^{*}$ & $(5.34)$ & $0.404^{*}$ & (5.47) & $0.414^{*}$ & $(5.59)$ \\
\hline Adj $R^{2}$ & 0.40 & & 040 & & 0.34 & & 0.34 & \\
\hline
\end{tabular}

* indicates that coefficient is significant at 1 percent level.

** indicates that coefficient is significant at 5 percent leve1.

*** indicates that coefficient is significant at 10 percent level.

Equation 3 included the interaction term. The inclusion of this variable reduced the coefficient of education from 0.048 to 0.040 . The coefficient of experience is also reduced from 0.067 to 0.060 . Evaluating at mean value of 
education (7.58), we find that earnings rise by 30 percent. Similarly earnings increase by 26 percent if experience is 11.08 years (mean value). An individual with education 7.58 years and experience of 11.08 years earns 6 percent more than an uneducated one having experience less than 5 years. These results imply that uneducated workers attain peak earnings after having an experience of 20 years. However, the maximum earnings at completed school years 5, 8, $10,12,14$ and 16 years are achieved at experience of 21.16, 21.86, 22.33, $22.80,23.26$ and 23.73 years $^{15}$.

In order to test the significance of the interaction term, we have applied the F-test that rejected the null hypothesis that education-experience interaction is not significant.

In equation 4 , instead of using $\mathrm{S}, \mathrm{E}$ and $\mathrm{E}^{2}$, we introduced 4 dummies for education and four dummies for employment experience $\left(S_{1}\right.$ and $E_{1}$ being the excluded categories). These estimates indicate the returns to education increase with increase in education. Similar trends are observed for employment experience.

In equation 5 we included nine dummies to capture the interaction between education and employment at different levels. The introduction of these interaction terms reduces the value of the coefficients of education dummies and the only significant dummy in the estimates is $S_{4}$. Similarly, the coefficients of employment experience dummies are also reduced at each level but remain statistically significant. On the other hand, only one interaction term $S_{4} E_{4}$ is found to be significantly different from zero. The significant coefficient of $S_{4} E_{4}$ implies that the workers with education matric and above with employment experience more than 15 years earn 27 percent more than those who have no education and employment experience less than 5 years. The F-test to examine the significance of these interaction terms indicates that the interaction terms are not significant. This means that there is no significant impact of education-experience interaction at different levels of education and experience, except the highest one.

These findings are further strengthened by examining the level of income at different levels of education (experience) holding experience (education) constant. Such statistics are presented in Table 5 where mean income is calculated for each education and experience category.

\footnotetext{
${ }^{15}$ For Tanzania, Knight and Sabot (1981) observe a similar trend. Mincer (1974) however found that individuals with higher levels of education achieve peak earning with shorter length of experience in the United States.
} 
Table 5: Mean Income at Different Levels of Education and Experience

\begin{tabular}{|c|c|c|c|c|c|}
\hline & & & & & Rupees) \\
\hline & E1 & E2 & E3 & E4 & Total \\
\hline S1 & 1,973 & 2,512 & 2,629 & 2,677 & 2,430 \\
\hline S2 & 2,015 & 2,953 & 2,930 & 3,230 & 2,650 \\
\hline S3 & 2,423 & 2,679 & 3,570 & 3,639 & 2,907 \\
\hline S4 & 3,386 & 4,069 & 4,989 & 5,857 & 4,372 \\
\hline Total & 2,783 & 3,381 & 4,003 & 4,300 & 3,495 \\
\hline
\end{tabular}

One can observe an increase in mean income as the educational level increases holding experience constant or increasing experience holding educational level constant. A considerable difference in the earnings of uneducated and educated at each level of experience can be noted from this Table. For example, one can see a negligible increase in income of the uneducated individuals belonging to experience group 3 and 4 , whereas this differential is considerable as education increases in the same experience groups. This shows that the experience-earning profile is steeper for the educated [see Appendix chart 3].

One of the striking features of Table 4 is the high and significant dummies of occupation in all four equations. Higher earnings are associated with better paying occupation ${ }^{16}$. According to equation 2 , professionals earn 50 percent, technical professionals 32 percent and service workers earn 25 percent higher than the labourers. Dropping these dummies from the regressions we found a decline in explained variation in all the equations ${ }^{17}$. In addition, a substantial rise in the coefficients of education and training has been observed (from 0.048 to 0.056 and from 0.094 to 0.115 respectively). In equation 4 when education is replaced by a set of dummy variables, we found expected magnitudes and signs of these dummies. This equation also showed higher coefficients of education at all levels. In equation 5 , significant coefficients of $S_{4}$, interaction dummy $S_{4} E_{4}$, and technical training indicate the importance of education and training in determining earnings. The role of these two variables is also very significant in the choice of occupation. For example, using the data of Israel, Neuman and Ziderman (1991) observed that the individuals with vocational school

\footnotetext{
${ }^{16}$ The occupations are classified according to the level of skills that workers have. The category 'Professionals' includes managers and other professionals; Technicians and other semi-professionals fall in the category 'Technicians'; the group 'Service' includes all skilled and semi-skilled workers; and general labour are combined in the category 'labour'.

${ }^{17}$ This set of estimated equations is not reported here.
} 
training working in their course-related discipline earn more (by up to 10 percent annually) than their counterparts who attended general secondary schools or work in noncourse-related occupations but are graduates of vocational schools.

\section{Effect of education, experience and occupation on earnings}

Another way of looking at the joint effect of education and experience on individual earnings is to stratify the sample according to the levels of employment experience (educational levels) and examine the coefficient of schooling (experience). Besides, in order to examine the effect of occupation on earnings we will stratify our sample according to occupations and examine the coefficients of education, experience and the education-experience interaction term.

\section{Effect of education on earnings at different levels of experience}

First we divide our sample into four experience groups, mentioned in the section of methodology and examine the returns to education at these levels of experience. The estimated earning functions for different levels of employment experience are reported in Table 6. This table shows that higher earnings are associated with higher experience. Looking at the regression estimates, one can note that as experience increases from 4 years to 14 years, the coefficient of education drops from 5 percent to 3.5 percent. This table shows that although the mean earnings at the lowest level of experience are lowest, the coefficient of education is considerably high. At this level of experience one additional year of education adds 5 percent more to earnings. This means that at early stages of employment, an individual needs to demonstrate his productivity. In this regard, both education and technical training play an important role. A decline in the coefficients of technical training and education with increase in experience indicates the productivity enhancing learning process that the individual acquires through experience. In other words, the effect of education reduces as experience increases. This table shows that in the highest experience group, returns to education are also highest. At this level of experience, the only significant occupation dummy is for the professionals. By dropping the occupational dummies from the regression we not only found a considerable decline in the explained variation but also a decline in the coefficient of education from 0.061 to 0.048 . This means that at higher levels of experience, occupation has a direct as well as indirect effect through education on individual earnings. 
Table 6: Earning Function Estimates at Different Levels of Experience

\begin{tabular}{llllllllll}
\hline & \multicolumn{3}{c}{ E1 } & \multicolumn{2}{c}{ E2 } & \multicolumn{2}{c}{ E3 } & \multicolumn{2}{c}{ E4 } \\
\cline { 2 - 9 } & $\beta$ & t-value & $\beta$ & t-value & $\beta$ & t-value & $\beta$ & t-value \\
\hline Const & 6.45 & $(34.76)$ & 6.98 & $(38.24)$ & 6.66 & $(22.66)$ & 6.71 & $(37.95)$ \\
S & $0.050^{*}$ & $(8.08)$ & $0.038^{*}$ & $(5.72)$ & $0.035^{*}$ & $(3.67)$ & $0.061^{*}$ & $(9.87)$ \\
Train & $0.208^{*}$ & $(2.34)$ & 0.06 & $(0.69)$ & 0.038 & $(0.03)$ & 0.083 & $(0.89)$ \\
Prof & $0.45^{*} 1$ & $(2.91)$ & $0.541^{*}$ & $(3.32)$ & $0.675^{*}$ & $(2.67)$ & $0.362^{*}$ & $(2.36)$ \\
Tech & $0.321^{* *}$ & $(2.29)$ & $0.343^{* *}$ & $(2.38)$ & $0.445^{* *}$ & $(2.00)$ & 0.159 & $(1.12)$ \\
Service & $0.240^{* * *}$ & $(1.91)$ & $0.268^{* *}$ & $(2.12)$ & 0.283 & $(1.42)$ & 0.184 & $(1.44)$ \\
Male & $0.549^{*}$ & $(6.12)$ & $0.287^{*}$ & $(2.98)$ & $0.555^{*}$ & $(3.01)$ & $0.530^{*}$ & $(4.65)$ \\
Urban & 0.007 & $(0.13)$ & $0.161^{*}$ & $(2.64)$ & 0.049 & $(0.51)$ & $0.276^{*}$ & $(4.48)$ \\
Punjab & -0.009 & $(0.12)$ & -0.064 & $(-0.67)$ & 0.177 & $(1.26)$ & 0.094 & $(1.19)$ \\
Sind & $0.670^{* *}$ & $(1.96)$ & 0.116 & $(1.20)$ & $0.368^{*}$ & $(2.59)$ & $0.227^{*}$ & $(2.54)$ \\
Baloch & $0.404^{*}$ & $(2.75)$ & 0.054 & $(0.35)$ & $0.582^{*}$ & $(3.23)$ & $0.510^{*}$ & $(4.35)$ \\
Adj $\mathrm{R}^{2}$ & 0.28 & & 0.27 & & 0.29 & & 0.46 & \\
$\mathrm{~N}$ & 442 & & 326 & & 171 & & 328 & \\
\hline
\end{tabular}

* indicates that coefficient is significant at 1 percent level.

** indicates that coefficient is significant at 5 percent leve1.

*** indicates that coefficient is significant at 10 percent level.

\section{Effect of experience on earnings at different levels of education}

The results of estimated earning function to examine the coefficient of experience at different levels of education are reported in Table 7 . These results show that returns to experience are increasing as education increases. Highest returns are associated with highest level of education. These results indicate that at lower levels of education, experience and training play an important role in raising income. The significant coefficient of training for primary and below indicates the importance of technical education especially for those who have some know-how. Looking at the occupation dummies, this table reveals that for the uneducated, the coefficient of "Services" and for the highest education category, the coefficient of "Professionals" is highest not only in size but also in the level of significance. The inclusion of $\mathrm{E}^{2}$ in the regression equations produces higher returns to experience for the uneducated than those who are primary or middle graduates. However, evaluating at mean years of experience ( 11.08 years) implies that uneducated and primary educated individuals with experience 11.08 years earn 47 percent and 41 percent more than the non-experienced workers. The differential in the earnings of experienced and non-experienced becomes wide as educational level improves to middle and high (55\% and 56\%). 
Table 7: Earning Function Estimates at Different Levels of Education

\begin{tabular}{lllllllll}
\hline & \multicolumn{2}{c}{ S1 } & \multicolumn{2}{c}{ S2 } & \multicolumn{2}{c}{ S3 } & \multicolumn{2}{c}{ S4 } \\
\cline { 2 - 9 } & $\beta$ & t-value & $\beta$ & t-value & $\beta$ & t-value & $\beta$ & t-value \\
\hline Const & 6.03 & $(32.76)$ & 7.23 & $(25.97)$ & 7.39 & $(39.08)$ & 6.89 & $(32.33)$ \\
E & 0.006 & $(1.70)$ & 0.016 & $(3.17)$ & 0.026 & $(5.86)$ & 0.029 & $(8.43)$ \\
Train & 0.003 & $(0.02)$ & 0.333 & $(2.65)$ & -0.102 & $(-0.79)$ & 0.085 & $(1.38)$ \\
Prof & 0.297 & $(1.62)$ & -0.324 & $(1.12)$ & 0.182 & $(0.86)$ & 0.716 & $(3.51)$ \\
Tech & 0.309 & $(2.18)$ & 0.108 & $(0.51)$ & 0.185 & $(0.88)$ & 0.453 & $(2.26)$ \\
Service & 0.345 & $(3.38)$ & 0.183 & $(1.29)$ & 0.167 & $(0.98)$ & 0.296 & $(1.48)$ \\
Male & 1.070 & $(9.50)$ & 0.205 & $(0.95)$ & - & - & 0.298 & $(4.33)$ \\
Urban & 0.138 & $(1.67)$ & 0.172 & $(2.00)$ & -0.087 & $(1.12)$ & 0.218 & $(4.59)$ \\
Punjab & -0.035 & $(-0.17)$ & -0.284 & $(-2.20)$ & 0.041 & $(0.36)$ & 0.160 & $(2.43)$ \\
Sind & 0.191 & $(2.38)$ & 0.009 & $(0.072)$ & 0.268 & $(2.38)$ & 0.279 & $(4.06)$ \\
Baloch & 0.491 & $(3.95)$ & 0.498 & $(1.98)$ & 0.420 & $(2.01)$ & 0.341 & $(3.09)$ \\
Adj R ${ }^{2}$ & 0.32 & & 0.22 & & 0.20 & & 0.25 & \\
N & 315 & & 155 & & 146 & & 642 & \\
\hline
\end{tabular}

* indicates that coefficient is significant at 1 percent level.

** indicates that coefficient is significant at 5 percent leve1.

*** indicates that coefficient is significant at 10 percent level.

\section{Effect of occupation on earnings}

It has been found that mean earnings differ substantially across occupations for the same level of education and experience. Table 8 shows that variation in earnings within an occupation across different levels of education is less than the variation within an educational or experience group across different occupations. For example, highly educated labourers earn 10 percent higher than uneducated labour whereas workers in the "Professional" category having education more than 8 years earn 66 percent more than the workers in the "Labour" category with the same level of education. Appendix chart 4 shows the variation in earnings within one occupation for different levels of education. The responsiveness in earnings to education is negligible for the labourer class. On the other hand, earnings are found highly sensitive for professionals. Appendix Chart 5 indicates similar trends for the experience groups that the differences in earnings across different experience levels for professionals are more pronounced than those of labourers. 
Table 8: Mean Earnings in Different Occupations for each Educational and Experience Group

\begin{tabular}{lllllllll}
\hline & S1 & S2 & S3 & S4 & E1 & E2 & E3 & E4 \\
\hline Labour & 1,824 & 1,799 & 2,429 & 2,025 & 1,603 & 1,834 & 2,133 & 2,208 \\
Service & 2,501 & 2,664 & 2,904 & 3,726 & 2,534 & 2,973 & 3,530 & 3,488 \\
Tech & 2,523 & 3,612 & 2,914 & 4,164 & 3,077 & 3,864 & 4,633 & 4,546 \\
Prof & 2,789 & 2,025 & 3,232 & 6,025 & 4,148 & 4,853 & 5,489 & 7,221 \\
\hline
\end{tabular}

The picture becomes clearer when we examine the coefficients of education, experience and education-experience interaction in the earning functions that are stratified according to occupations ${ }^{18}$. These results are presented in Table 9. One can note from the estimated equations that the coefficient of experience rises as the occupational category improves. This indicates that the individuals in better occupational categories learn more with experience. A similar trend can be seen in the returns to education with the exception of the "Labour" category, where returns to education are higher than the "Service workers". One year increase in the education of "Professionals" increases their earnings by 9 percent whereas this increase is only 5 percent for the labourers. Similarly, one year increase in experience brings about an increase of 9 percent in the earnings of "Professional" workers, while this increase is only 4 percent for the labourers. The professionals, technical workers and service workers attain peak earnings after experience of 21, 21 and 22 years whereas Labourers need an experience of 33 years to attain peak earnings. This implies that an individual in a better occupation attains peak earnings at lesser experience.

\footnotetext{
${ }^{18}$ The education-experience interaction terms was found insignificant. Therefore we have dropped this variable and re-estimated the earning functions for each occupational category.
} 
Table 9: Earning Function for Different Occupations

\begin{tabular}{lllllllll}
\hline & \multicolumn{2}{c}{ Labour } & \multicolumn{2}{c}{ Service } & \multicolumn{2}{c}{ Tech } & \multicolumn{2}{c}{ Prof } \\
\cline { 2 - 9 } & $\beta$ & t-value & $\beta$ & t-value & $\beta$ & t-value & $\beta$ & t-value \\
\hline Const & 5.12 & $(11.32)$ & 6.14 & $(52.06)$ & 6.74 & $(50.04)$ & 6.26 & $(31.58)$ \\
$\mathrm{S}$ & $0.051^{*}$ & $(3.76)$ & $0.035^{*}$ & $(8.26)$ & $0.03^{*}$ & $(7.58)$ & $0.086^{*}$ & $(7.95)$ \\
$\mathrm{E}$ & $0.039^{* *}$ & $(2.15)$ & $0.066^{*}$ & $(9.07)$ & $0.067^{*}$ & $(6.69)$ & $0.085^{*}$ & $(5.36)$ \\
$\mathrm{E}^{2}$ & -0.0006 & $(-1.23)$ & - & $(-6.95)$ & - & $(-5.39)$ & $-0.0019^{*}$ & $(-4.27)$ \\
& & & $0.0015^{*}$ & & $0.001^{*} 6$ & & & \\
Train & 0.163 & $(0.57)$ & 0.006 & $(0.93)$ & 0.005 & $(0.05)$ & 0.107 & $(0.99)$ \\
Male & $0.982^{*}$ & $(2.48)$ & $0.970^{*}$ & $(9.96)$ & $0.235^{*}$ & $(3.06)$ & $0.256^{*}$ & $(2.25)$ \\
Urban & $0.269^{* * *}$ & $(1.80)$ & $0.089^{* *}$ & $(2.16)$ & $0.156^{*}$ & $(2.67)$ & $0.272^{*}$ & $(2.76)$ \\
Punja & $0.703^{*}$ & $(2.98)$ & 0.016 & $(0.26)$ & 0.041 & $(0.53)$ & $0.061^{*}$ & $(5.25)$ \\
b & & & & & & & & \\
Sind & $1.050^{*}$ & $(4.61)$ & $0.168^{*}$ & $(2.58)$ & 0.040 & $(0.47)$ & $0.204^{* * *}$ & $(1.67)$ \\
Baloch & $1.049^{*}$ & $(3.53)$ & $0.419^{*}$ & $(4.33)$ & 0.200 & $(1.61)$ & $0.692^{*}$ & $(3.49)$ \\
Adj $\mathrm{R}^{2}$ & 0.42 & & 0.33 & & 0.30 & & 0.48 & \\
$\mathrm{~N}$ & 70 & & 713 & & 320 & & 164 & \\
\hline
\end{tabular}

* indicates that coefficient is significant at 1 percent level.

** indicates that coefficient is significant at 5 percent leve1.

*** indicates that coefficient is significant at 10 percent level.

It is interesting to note that the coefficient of the educationexperience interaction was significant in the full sample regressions presented in Table 4, but it is found insignificant when we divide workers according to their occupations (Table 9) ${ }^{19}$. It implies that education and experience affect earnings differently in different occupations. This is because some occupations require high skilled workers. And the individuals with better level of education can learn those skills more quickly with their experience. Therefore both the returns to experience and returns to education are higher for those who choose a better occupation.

To further explore the effect of occupational choice, we examined the pattern of earnings not only across occupation for the same level of education but also across different levels of education for the same occupation $^{20}$. The results are reported in Table 10. This Table shows an obvious earning differential across occupations for the same level of education and experience as compared to that noted within an occupation for different levels of experience holding education constant. This table

\footnotetext{
${ }^{19}$ For Tanzania, Knight and Sabot (1981) also observed significant interaction term in the full sample and insignificant in the stratified sample.

${ }^{20}$ In order to examine the effect of occupation for the same level of education, we chose only those individuals who have education of more than five years. And the effect of education for the same occupation has been explored by restricting the sample only to service workers.
} 
illustrates the variables that have a stronger effect on earnings: from amongst occupation, education or experience.

Table 10: Earnings Differentials Across Occupations and Educational Levels for Different Levels of Experience

\begin{tabular}{rrrrrrrrr}
\hline & \multicolumn{4}{c}{$\mathbf{S} \geq \mathbf{5}$} & \multicolumn{4}{c}{ Occupation=Service } \\
\cline { 2 - 9 } & Prof & Tech & Service & Labour & S1 & S2 & S3 & S4 \\
\hline E1 & 4,927 & 3,137 & 2,747 & 1,809 & 2,019 & 2,094 & 2,398 & 3,179 \\
E2 & 4,942 & 3,801 & 3,236 & 2,205 & 2,572 & 2,923 & 2,705 & 3,555 \\
E3 & 5,692 & 4,784 & 3,996 & 2,750 & 2,703 & 2,834 & 3,637 & 4,626 \\
E4 & 7,787 & 4,905 & 4,117 & 3,150 & 2,813 & 3,368 & 3,698 & 3,726 \\
\hline
\end{tabular}

To illustrate this we choose one occupation 'Service', and one experience leve1 E3 (8-12 years) and examine variation within and across occupation, education and experience. We note that the differential in the earnings of professionals and labourers with the same education $(\mathrm{S} \geq 5)$ and same experience level (E3) is 52 percent. This difference between uneducated and highly educated within the same occupation (Service) and same experience level (E3) is 42 percent. And the difference in the earnings of least experienced workers and those having experience of 8-12 years within the same occupation (Service) and same educational level $(\mathrm{S} \geq 5)$ is 31 percent. This indicates that the effect of choice of occupation is stronger than the effect of education and the effect of education is stronger than the effect of experience. We can conclude from the above discussion that in Pakistan's labour market, occupational choice is more important than education and education is more important than experience for higher earnings. However, a positive association between high mean years of education and better occupation indicates that in addition to employment opportunities, education plays an important role in choosing an occupation. There is a need to explore this causal relationship.

\section{Conclusions}

This paper examines the effects of education, experience and occupation on individual earnings in Pakistan for wage earners and salaried persons. The results of this paper indicate that the education-experience interaction has a positive and significant impact on earnings. However, when the earning functions are stratified according to experience groups, the returns to education are found to be declining as experience lengthens. On 
the other hand, the stratification according to educational groups indicates that the returns to experience rise as educational level improves. In addition to these, this analysis also finds that the rise in earnings with experience at the highest educational level is much greater than that at lower educational levels. This implies that education plays a crucial role not only when an individual enters the job market but also in enhancing the post school human capital formation, gained through experience. Technical training was found to have a large and significant impact on those who have experience either less than 5 years or have education of at least primary.

Another important finding is that there exist significant differences in earnings across occupations. The effect of occupational choice is found to be stronger than the effect of education and the effect of education is observed to be stronger than the effect of experience. For example: the differential in the earnings of professionals and labourers with the same education ( $\mathrm{S} \geq 5)$ and same experience level (E3) is 52 percent. This difference between uneducated and highly educated within the same occupation (service) and same experience level (E3) is 42 percent. And the difference in the earnings of least experienced workers and those having experience of 812 years within the same occupation (service) and same educational leve1 $(\mathrm{S} \geq 5)$ is 31 percent. This indicates that the effect of choice of occupation is stronger than the effect of education and the effect of education is stronger than the effect of experience. A positive association between high mean years of education and better occupation highlights the importance of education in choosing a better occupation. This paper found significant earning differentials across gender, region and provinces, especially when the earning functions are stratified by occupation groups.

\section{Policy Implications and Recommendations:}

The findings discussed above have six main policy implications.

1. A stronger effect of education than experience suggests the need for expansions and improvements in the education sector. Therefore attention should be given to improve the quality of education in addition to increasing the educational infrastructure.

2. A positive and significant impact of technical training for those who have primary or below level of education points to the need of such institutions that can provide training, especially to those who are less educated. In Pakistan, the existing number of formal technical and vocational training institutes is not sufficient to cater to the demand for technical education. Moreover, due to the lack of communication between these 
institutions and the industrial establishment, the labour absorption rate of these graduates is low [see Butt (1993)]. Therefore, there is a need not only to increase the number of such institutions but also to increase their coverage to all areas. Coordination between these institutions and the industrial establishment would certainly play a positive role not only in obtaining employment but also in choosing an occupation that is found to be a very important determinant of earnings in the present study.

3. The importance of the choice of occupation brings to light the very important issue of available employment opportunities in Pakistan's labour market. Significant earning differentials across gender, region and provinces reflect uneven distribution of employment opportunities for males and females; rural and urban areas; and in four provinces of Pakistan. Therefore urgent measures are needed to create equity by eliminating these differences. There is a need to promote girls education, to develop the rural economy and to ensure even distribution of all social services and employment opportunities across provinces and regions.

4. A positive association between education and better occupation indicates that in addition to employment opportunities, education plays an important role in choosing an occupation. Unfortunately, on the one hand, due to high rate of illiteracy and low educational attainments, Pakistan's labour market is dominated by uneducated or less educated persons and on the other hand, a large number of educated persons are unemployed $^{21}$. The lack of job opportunities is a significant reason of the high rate of brain drain from the country. There is an urgent need to pay attention to this very important issue and design such policies that help in the optimal utilisation of skilled human resources of the country.

5. There is a great need to collect detailed information on work experience, i.e., past and present employment history that is presently lacking in most of the household surveys in order to further investigate the effects of human capital accumulation.

6. A positive association between high mean years of education and better occupation highlights the importance of education in choosing a better occupation. This analysis, however, does not explore the causal

21 The Labour Force Survey (2001-02) reports that 3.57 million persons were unemployed in Pakistan in 2001-02; 45 percent were illiterate and 55 percent were literate. Among literate unemployed, 5.9 percent held higher and professional degrees. 
relationship between education and occupation. Such exploration would provide useful insights into human capital formation and utilisation. 
24 The Lahore Journal of Economics, Vol.9, No. 2

\section{References}

Ahmad, E., M. F. Arshad and A. Ahmad, 1991, "Learning and Earning Profiles in Pakistan's Informal Sector”. Pakistan Economic and Social Review. Vol. XXIX, No. 2

Anderson, Lascelles, 1980, "Rates of Returns to Human Capital: A Test Using E1 Salvador Data" American Economic Review, Papers and Proceedings. 70(2): 738-41.

Arif, G. M., S. Mubashir Ali, Z. M. Nasir, and Nabeela Arshad, 1999, "An Introduction to Pakistan Socio-Economic Survey." Mimeo. Pakistan Institute of Development Economics. Islamabad.

Arif, G. M., Hina Nazli, and Rashida Haq, 2000, "Basic MIMAP Poverty Profile of Pakistan”. Paper presented in the Conference of MIMAP in Manila. September 2000.

Ashraf, B. and J. Ashraf, 1996, "Evidence on Gender Wage Discrimination from the 1984-85 HIES: A Note”. Pakistan Journal of Applied Economics. Vol. XII, No. 1.

Ashraf, J. and B. Ashraf, 1993a, "Estimating the Gender Wage Gap in Rawalpindi City”. Journal of Development Studies. Vo1. 24, No. 2.

Ashraf, J. and B. Ashraf, 1993b, "An Analysis of the Male-Female Earning Differential in Pakistan”. The Pakistan Development Review. Vo1. 32, No. 4.

Becker, Gary S., 1962, "Investment in Human Capital: A Theoretical Analysis". Journal of Political Economy. Vo1. 70, Supplement.

Blaug, Mark, 1976, "Human Capital Theory: A Slightly Jaundiced View". Journal of Economic Literature. 14(3): 827-55.

Butt, Rafiq M., 1993, "Monitoring and Evaluation of Vocational and Technical Education in Pakistan”. In Hyder, S. N., (ed) (1993), Towards an Integrated Human Resource Development Planning in Pakistan. UNDP/ILO/PMI, Islamabad.

Byron, Raymond. P. and Evelyn Q. Manaloto, 1990, "Returns to Education in China”. Economic Development and Cultural Change. 
Byron, R. P. and H. Takahashi, 1989, "A Note on the Effect of Schooling, Experience and Sex on Earnings in the Government and Private Sectors of Urban Java”. Bulletin of Indonesian Economic Studies 25: 105-17.

Connolly, Helen and Peter Gottschalk, 2003, Returns to Tenure and Experience Revisited: Do Less Educated Workers Gain Less from Work Experience? www.ifs.org.uk/

de Beyer, Joy, and J. B. Knight, 1989, "The Role of Occupation in the Determinants of Wages”. Oxford Economic Papers. 41(3): 595-618.

Ehrenberg, G. R. and S. R. Smith, 1997, Modern Labour Economics: Theory and Public Policy. Addison-Wesley, Reading, Mass.

Government of Pakistan, 2001-02, Pakistan Labour Force Survey 2001-02. Federal Bureau of Statistics.

Government of Pakistan, 2001-02, Pakistan Integrated Household Survey 200102. Federal Bureau of Statistics.

Fafchamps, Marcel and Agnes R. Quisumbing, 1998, Human Capital, Productivity, and Labor Allocation in Rural Pakistan. FCND Discussion Paper No. 48. Food Consumption and Nutrition Division. International Food Policy Research Institute. Washington, D.C.

Ferrall, Christopher, 1997, "Empirical Analysis of Occupational Hierarchies." Journal of Human Resources 32(1):1-34.

Guisinger, S. E., J. W. Henderson, and G. W. Scully, 1984, "Earnings, rate of Returns to Education and Earning Distribution in Pakistan". Economics of Education Review. Vol. 3, No. 4.

Hamdani, Khalil, 1977, "Education and the Income Differentials: An Estimation of Rawalpindi City”. The Pakistan Development Review. Vol. XVI No. 2.

Haque, Nadeemul, 1977, "An Economic Analysis of Personal Earnings in Rawalpindi City". The Pakistan Development Review. 16:4.

Jimenez, E. and B. Kugler, 1986, "The Earnings, Impact of Training Duration in a Developing Country" Journal of Human Resources. Volume 76: 604-20. 
Khan, S. R. and M. Irfan, 1985, "Rate of Returns to Education and Determinants of Earnings in Pakistan". The Pakistan Development Review. 34:3\&4.

Khandker, S. R., 1990, "Labour Market Participation, Returns to Education, and Male-Female wage Differentials in Peru". Working Paper No. 461. Population and Human Resource Department, The World Bank. Washington, D.C.

King, E. M., 1990, "Does Education Pay in the Labour Market? The Labour Force Participation, Occupation and Earnings of Peruvian Women". Living Standard Measurement Study. Working Paper No. 67. The World Bank. Washington, D.C.

Kirby, Simon and Rebecca Riley, 2004, "The returns to schooling and jobspecific experience: the role of ICT technology". National Institute of Economic and Social Research, London

Knight, J. B., 1979, "Job Competition, Occupational Production Functions, and Filtering Down”. Oxford Economic Papers. 31(2): 187-204.

Knight, J. B. and R. H. Sabot, 1990, Educational Productivity and Inequality: The East African Natural Experiment Oxford University Press. New York.

Knight, J. B., and R. H. Sabot, 1981, "The Returns to Education: Increasing with Experience or Decreasing with Expansion". Oxford Bulletin of Economics and Statistics. 43(1): 51-71.

Layard, Richard and G. Psacharopoulos, 1974, "The Screening Hypothesis and the Social Returns to education". Journal of Political Economy. 82 (October): 985-98.

Malik, Sohail. J. and Hina Nazli, 2003, "Determinants of Poverty in Rural and Urban Areas: Evidence from Punjab”. IDS working paper No. 1. Innovative Development Strategies (Pvt.) Ltd. Islamabad, Pakistan.

Mazumdar, Dipak, 1981, The Urban Labour Market and Income Distribution. New York: Oxford University Press.

Mincer, Jacob, 1974, Schooling, Experience and Earnings: New York: National Bureau of Economic Research. 
Nasir, Z., M. and Hina Nazli, 2000, "Education and Earnings in Pakistan". Research Report No 177. Pakistan institute of Development Economics. Islamabad.

Nasir, Z. M., 1999, "Do Private Schools Make Workers More Productive". Pakistan Institute of Development Economics. Mimeo.

Neuman, Shoshana and Adrian Ziderman, 1991, "Vocational Schooling, Occupational Matching, and Labor Market Earnings in Israel." Journal of Human Resources 26(2):256-281.

Psacharopoulos George, 1981, "Returns to Education: An Updated International Comparison”. Comparative Education 17(3): 123-33.

Shabbir, T. and A. H. Khan, 1991, "Mincerian Earning Functions for Pakistan: A Regional Analysis". Pakistan Economic and Social Review. Vo1. XXIX, No. 2.

Shabbir, Tayyab, 1991, "Sheepskin Effects in the Returns to Education in a Developing Country”. The Pakistan Development Review. Vol. 30, No. 1.

Shabbir, Tayyab, 1993, "Productivity-Enhancing Vs Credentialist Effects of Schooling in Rural Pakistan”. International Food Policy Research Institute.

Shabbir, Tayyab, 1994, "Mincerian Earning Functions for Pakistan". The Pakistan Development Review. Vol. 33, No. 1.

van der Gaag, Jacques and Wim Vijverberg, 1989, "Wage Determinants in Côte d'Ivorie: Experience, Credentials and Human Capital." Economic Development and Cultural Change, 37:2. 
28 The Lahore Journal of Economics, Vol.9, No.2

Appendix Chart 1: Gender Differentials in Age-Earning Profile at S1

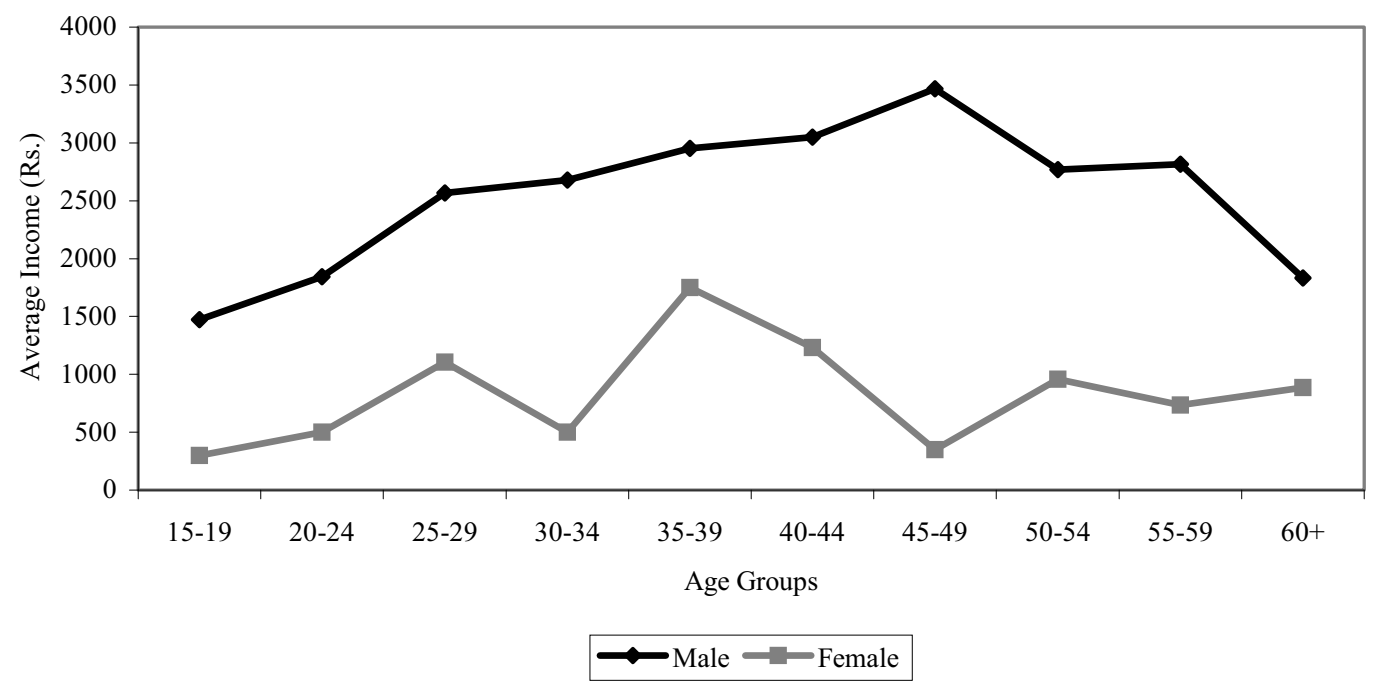

Appendix Chart 2: Gender Differential in Age-Earning Profile at S4

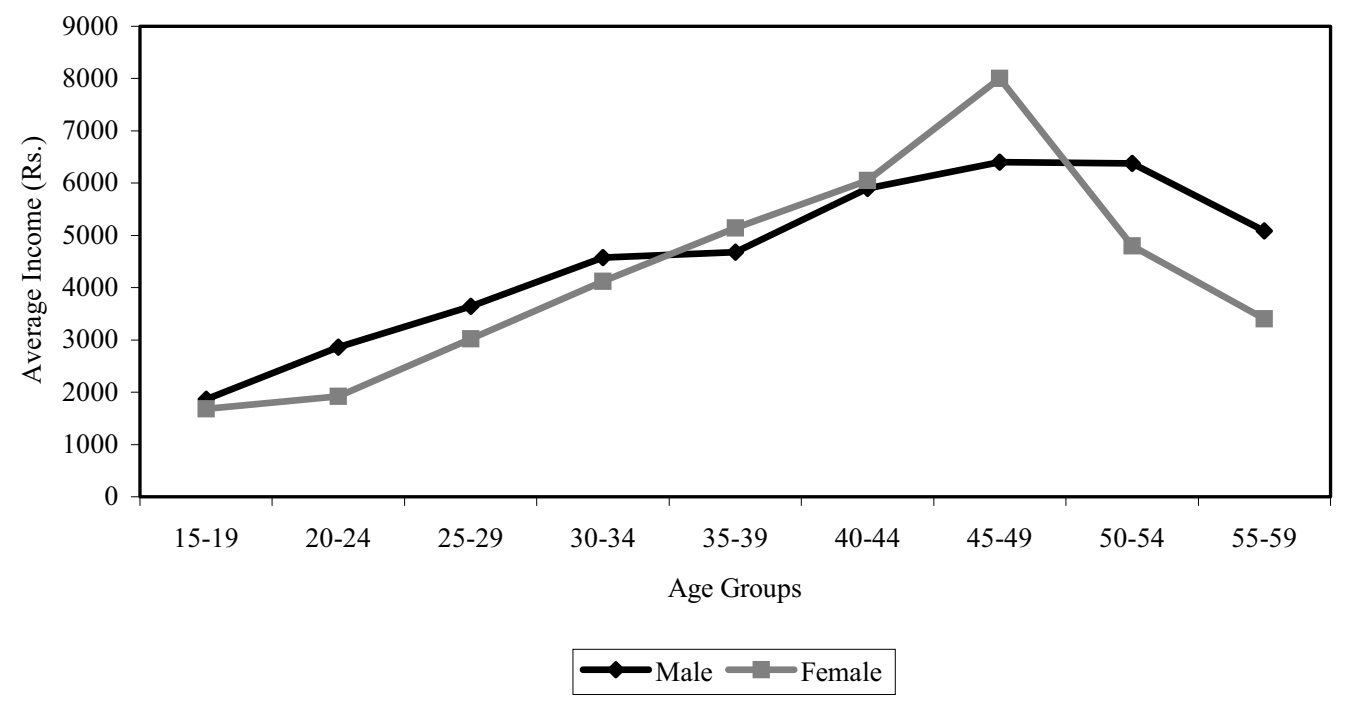


Appendix Chart 3: Earnings at Different Levels of Education and Experience

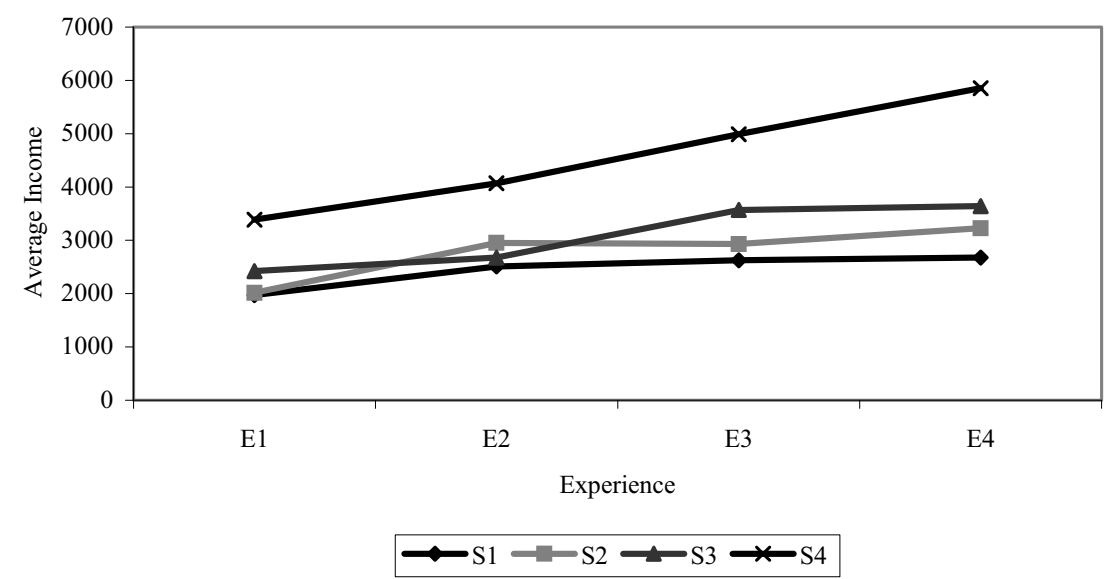

Appendix Chart 4: Occupational Earning Differentals within Each Educational Group

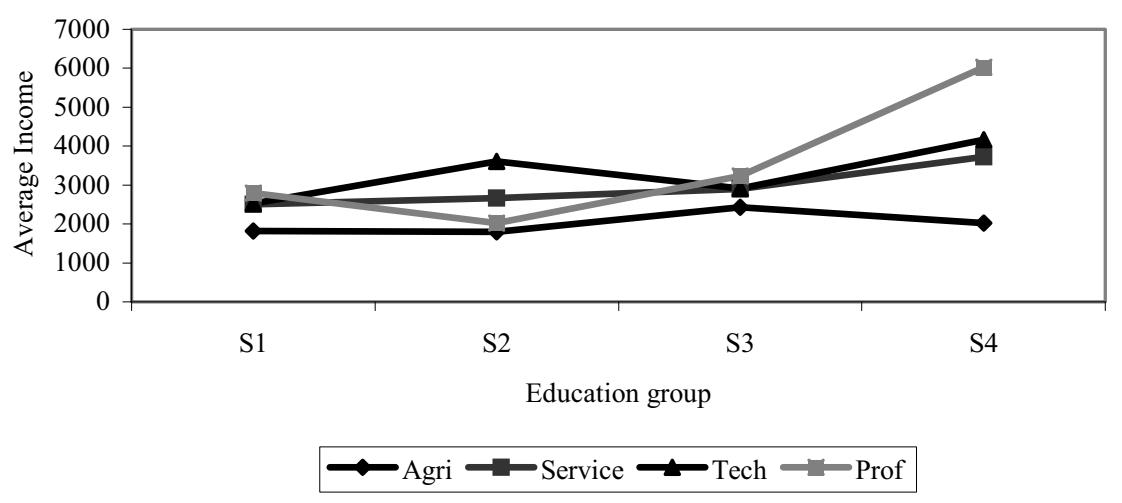


30 The Lahore Journal of Economics, Vol.9, No.2

Appendix Chart 5: Occupational Earning Differentials within Each Experience Group

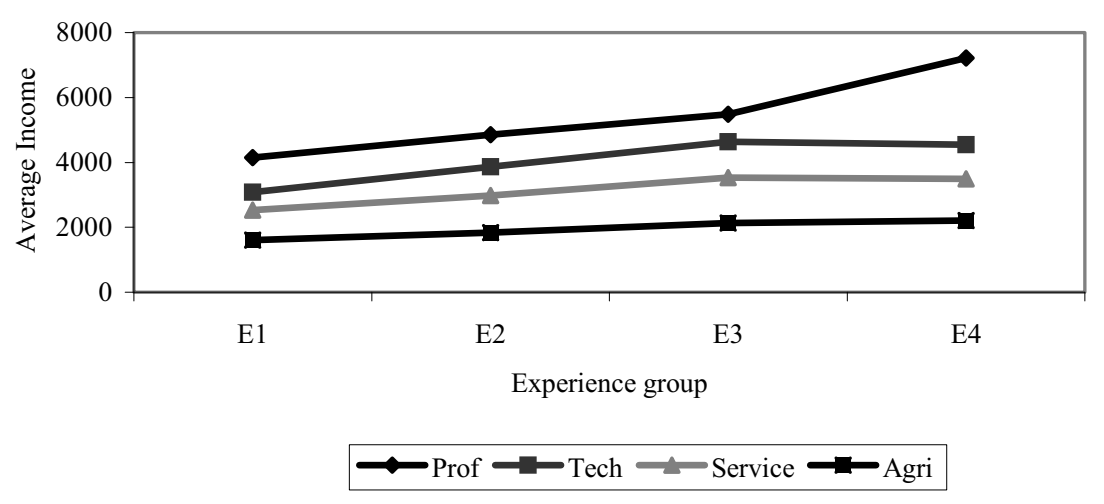

